\title{
Ivory Trade and Impact on Elephant Habitat and Population in Benguela 1790 - 1810
}

\author{
Edgar Teles \\ Faculty of Social and Human Sciences, New University of Lisbon, Portugal \\ Received October 18, 2019; Revised March 13, 2020; Accepted April 19, 2020
}

Copyright $\odot 2020$ by authors, all rights reserved. Authors agree that this article remains permanently open access under the terms of the Creative Commons Attribution License 4.0 International License

\begin{abstract}
This paper's subject is the inquiry of the impact of ivory consumption on elephant populations and their habitat in the course of the trading routes, in the late XVIII century and in the beginning of the XIX century $(1790$ - 1810) Angola. The information and the analyses for this paper was gathered and established, while doing research for a presentation in the Faculty of letters of the University of Lisbon; for an international conference where it was brought a study related to the Ivory trade from the port of Benguela to Lisbon in the mentioned period. Where, while undergoing the research, the author understood that it could be provided a quantitative universe related to the elephant population hunted in that region due Ivory demand. To undertake this article, the author consulted information available in several Portuguese archives, where he collected several documents that permitted him, based in quantitative sources, to establish an interpretation of the population of pachyderms hunted during the mentioned period. Another base of this essay, beside the quantitative data, is the references collected in XVI - XVIII century Chronicles about Angola, to establish in consonance with the archivist call sources, correlation between the hunting of the elephants with the impact, it caused in its habitat through that period. Keeping its interest in the interconnection of fields, the author investigates the notion of conservation in this period. In this case, the author tries to identify how many elephants were killed, and in what ages correspond to the most killing.
\end{abstract}

Keywords Ivory, Elephant in XVIII Century, Economy and Ecology, Elephants

\section{Introduction}

When we tackle a subject like elephant hunting and ivory trade, it is recurrent to the contemporary imaginary transport the subject to present days neglecting its historical context. While in preparation of a paper related to the Ivory trade of Benguela with Lisbon in the end of the XVIII century; it was formulated the hypothesis to extend the field of research to the source of the same good, the elephant. In the process of finding the proper literature regarding the Ivory, it become obvious that there is very few scholar historical inquires related to the mentioned pachyderm. Before we begin to define the intellectual boundaries of this essay, it is required to define the concept of ivory. In what concerns the referred good there is a wide diversity of sources, from which can be extracted. This object, besides referring to tusks, can also refer to dentine or tooth associated to the following animals: mammoth; walruses; wild boar; hippopotamus; or sperm whale. But, beside of animal origin, it may be of vegetal origin. There is a plant in South America, the palm ivory (phytelephas), that its endosperm known as the tagua or corozo nuts is similar (due to its appearance and how it can be carved) to elephant ivory [1]. In the context of this essay, tusks will only refer to the one extracted from the elephant.

The Portuguese sources related to the XVIII century, provide consistent information about elephant tusks and its commercialization to Portugal (either by the Atlantic routes or directly from Benguela to Lisbon). May, however, the works related to the subject in study be elaborated only in economic perspective? The same sources that permit us to study ivory, present us information directly or indirectly about a multitude of work hypothesis. The killing of elephants presupposes reduction of population, as well of the geographic space that corresponded to its habitat. To establish the mentioned vectors (geographic and demographic outlines), it is required to research the proper documentation and literature. In that contour of investigation, related with the question of elephant population, knowing the number of tusks establishes a departing point to inquiry about how much elements of the species were killed. Several solutions to resolve that scholar doubt where attempted, since documental research, 
to mathematical equations, in an attempt to provide a statistical dimension. The solution however was not achieved through a mathematically complex equation, or either result of an intense archive research. In the process of determining the accurate number of dead elephants, it was developed a very simple mathematical operation to provide the correct statistical value.

If, as methodological approach, it implies economy and (in the case of the tusks), the study of species from where it is derived; it can also be researched in relation to its habitat and population. To study this proposed object, it is required to establish the elephant habitat for those centuries, recurring to the written sources.

Therefore, I propose, the following structure to this article:

1. A brief survey on the Ivory collected in Angola and impact on elephant population in the XVIII Century.

2. Habitat of the Elephant in Angola, according with multiple sources.

\section{Materials and Methods}

\subsection{Documents and Archives}

How can the XVII - XVIII century sources provide us information about this species? When writing a work in the historical field, one question always to be considered it is related to the material in which it will be based. Therefore is pertinent to examine the sources that were used, due to the importance of the selection of the primary materials (that must obey to several criteria to insure the viability of the information). About this question, Cipolla, states the importance, even for consistency, of defining the basic documentation in a university research in order to provide the most complete information as possible. Recurring from that logic is the perspective of complementary different points of views and subjects within a theme in discussion, allowing to reduce lacunas and omissions that could exist with the utilization of only one source [2].The application of an extensive number of primarily materials in many cases, allows different interpretations and perceptions over a research object; what can offer debate, critics, and scholar questioning; with the consequent deepener and more complexity of the results. Another interrogation raised by Crosby, in what relates to ecological sources, was the need to expand the typology of sources beyond colonial records: to fire; water; animals and oral history [3]. In his standpoint, there are some barriers in accessing the archives and several of the regions for field study (in an anthropological methodological approach).Second there is, in this author opinion, little environmental archaeological or history of ecology within the African academicals world. Third, the multiplicity of languages (more then 2000), make it difficult to undergo coherent and operable field investigation [3]. Unquestionable that oral history provides us interesting information, and the study of elements cold provide innovating details not supplied by the written document; but hardly, when the subject of study its complete series and numerical data. The study of a species can correlate with all that lines of investigation except, those research topics very difficultly provide statistic details reverse to the written sources. Due to the question of the choice of documentation it is pertinent to ask, why Benguela and Luanda? For the chronological segment of this study, the sources about Benguela have more suitably series (better organized and coherent) that allowed me to establish a statistic tendency for a period of thirty years, nevertheless in what relates to habitat information, Luanda, possesses the more complex, and the more detailed information.

Established the theoretical criteria about the sources, let us present the different archives from where the documental information was collected and how the information was developed in this article. The information of the documents recoiled from the Overseas Historical Archive (A.H.U), in the avulso documents from the series related to Angola where, I've given priority to city map of Benguela data due to its rich statistical information regarding elephant tusks; primordial to determinate the number of elephants killed and tusks collected in the mentioned city. This source provides a description by type of tusk, in the early years of this chronological segment, and the totality of tusks brought to Benguela in general numbers. Other source, Kingdom Trade Balance available in the National Institute of Statistics (I.N.E), possesses some export information about the ivory provided from Angola. Nevertheless, it delivers fragmentary information about the ivory that came from Luanda, and non-about what was sent from Benguela. The third and last archive consulted the ANTT/TORRE DO TOMBO possesses, in the documental funds of the Casa da Índia, the records of the Entrada de Marfim. In this documentary collection Ivory contains well-discriminated information; by weight category, size, and the number of tusks. What permit us to establish the difference between age categories, beside the totality of tusks commercialized to Portugal in this period? Opposite to the Kingdom Trade Balance, the data supplied by this source its more complete allowing us to establish and organize more coherent information.

If the archive documents provide solid number about elephant tusks, their quite laconic about specific areas from where the tusks were brought and inherently where elephant may have lived. That absence of information obliges us to search other type of documents that may present us some clue about that question. Other typology of source consulted, more qualitative, were the chronicles and other descriptive texts that do not consist in archive material (documents). Due to the extensive variety of subjects that a chronicle can provide like: political, diplomatically, military history; circumstance that direct us to display a synthesis about the principal information that 
can be gathered related to the elephant. The major objective of those literal documents, in relation to Angola, was to inform the Portuguese crown about: political powers, military activity, populations, fauna, and flora present in that region. The descriptive nature of those texts opens the possibility to encounter and to define where the area where the elephant habited was. With that heuristic exercise in thought, three different sources were carefully chosen: Duarte Lopes \& Filipo Pigateffa, Relação do Reino do Congo; P. João António Cavazzi, Descrição Histórica dos três reinos do Congo, Matamba, Angola and António Cadornega, História das Guerras de Angola. The main motive behind the selection of these sources was the collected information and, as well, the different information's provided about the case study. Had established the selection criteria and the non-archive material, lets then inquire the content of each chronicle related with the object of study. About the first source, Relação do Reino do Congo, in a general observation, it is valorized by the observations of Duarte Lopes that was present in those regions as a merchant, providing accurate description; as well by the humanism writing of Fillipo Pigafeta [4]. The first offered some knowledge about the people and fauna of Congo and Angola that allow us to perceive where some of the species lived. About the priest João António Cavazzi was in that region for several years like a Capuchinho vicar that had an evangelization mission in Congo and in Matamba. Most of its material was recoiled not by his own travels, but by the letters and sources that Jesuits wrote about that specific region [5]. In the first volume of his mentioned work he provides us a description about animal species and the different provinces of Congo and Matamba, detailing its wild life in. António Cadornega was a military that fought in Angola for a period of 41 years from $1639-1690$, and collected its material within its personal experience, sources in Luanda, and reports of its military associates. In spite of the primary objective was the perpetuation of the memories of Portuguese military honors, the third volume has a wide geographical and ethnographic description [6]. Beside that volume, the ones that precede him describe some isolated episodes involving the elephant. Another source was Elias Correia Historia of Angola composed in the end of the XVIII century. The same author refrains of elaborate and extensive report on the fauna of Angola, but nevertheless provides merchant information. This chronicle first volume it is constituted by: the description of Angola, the harbours, jurisdictions, fortifications, several information's about the religious life, military and the economy as well about the economic problems of Angola. This author, had as base of information: chronicles, documentation of the archives of Angola, foreigner works, empirical information, ancient reports orals and writing, of ancient governors and crown officials that operated in that region [6]. In this volume; the author provides some information about ivory trade, and subsequently the geographical spaces where the case study may be found. Those three sources, provides us information given by three different chroniclers with different formation, and with different observations over fauna and flora.

\subsection{Literature Revision Economic and Ecological History in the Historiography of Africa Coexistence/Connections}

Had inquire the different sources that will be the raw information, it is required to proceed to the literature revision. Studding Africa under the ecological and environmental point of view, represents challenges in which the historian must experience new methodological encounters and perceptions; without, nevertheless, abandoned its traditional hermeneutical and heuristically proceedings connecting them, nonetheless, with natural history. The inquiry from which this investigation begins, involves three different subjects: ivory; elephants; and ecological/environmental thought. Due to the multitude of elements that compose the theoretical construction of this essay, it's required to proceed to the literature revision of the following disciples and investigation subjects: ecological/environmental African history; ivory and how historians have studied the elephant, departing from the most relevant theories connected with the investigation objectives.

This field could be connected with the Imperial ecology that by any extent studies plant and ecosystem alteration by human action [7]. But, could the research be limited, to that topic? What about the exploit of natural resources (animal and vegetal)? And, in what method these concepts, and fields' research, could this be integrate within Early Modern World? In order to better acknowledge and organize the information, I suggest we continue from African environmental/ecological Historiography. To know how we can efficiently study ivory and elephant, we must first know the main research themes in the mentioned academicals field properly; so those subjects could be integrated in the general debate. In a common observation environmental history, is considered an extensive field research that compresses several sciences and its history: ecology; botany; zoology; bacteriology; medicine; geology; and chemistry [8]. In the reading of Eugene P. Odum, ecological studies are more related with natural and exact sciences [9] although; can we just restrict their multidisciplinary connections to those disciplines? Some attempts have been made, in different areas and in connection with different fields, to elaborate a historical perception in ecological/environmental studies. In spite of the mentioned author favored natural sciences, he also underlines the importance of the historical study in regional context, to identify native fauna and flora, and changing brought by men's action [9]. African scholars in more recent studies elaborated as objective the understanding of natural cause and effect as a base of investigation of the environmental history. Within the first academic research, 
subjects like: colonial incursions, including appropriation of natural resources such as wildlife, forests, minerals, and land use by companies and settler; are in order [10]. More recently de lines of debate discussed subjects like: geography and topography, climate, water resources, and biota (floral and faunal) in relation with human histories (social, economic, cultural, or political) and its transformation in the course of time [3]. Other researches favor interdisciplinary interaction with: geography and natural and medical scientists [10]. As part of that historical tradition Beinart and McGregor, in connection with social history and African environments, offer a trio of themes when considering the African environmental history production as a whole: African environmental ideas and practices; colonial science, the state and African responses; settlers and Africans, culture, and nature [3]. But, what has been written about wild life exploration, in colonial period prior to XIX century and using non-Anglo-Saxonic sources? From those debates a school raised in the 1980's, the ecology inspired by Aldo Leopoldo, they suggest a method that compasses a dynamic nature, and not a static one, interconnected by a variety of influences [11]. Consequently, what can we do to trace the history of the Elephant in Africa? One of the most continuous obstacles to the elaboration of this paper, was the reduced inquires, in a historical perception, about this species. There is a book written by Raman Sukumar that investigates the history of the species in Asia in a multiple of questions like: origin of the species, relation with humans and habits. Towards the African Elephant he makes a small survey of its use in Antiquity for war and for Ivory [12], themes that are not in discussion within this article. One study conducted by a multiple perspective was the one directed by Durant $\mathrm{H}$. Ross, were the African Elephant it is researched in terms of: economy; symbolic value; ivory; art and ecology (its impact on is environment). In virtue of possess an extensive content, a general observation about the relevance of this study it is in order (more specific information will be mentioned in the appropriate points). The main achievement of this book was to provide a starting point about the elephant, compassing studies related do British Africa in a university perception; which amplified its studies in a plural-disciplinary field. Can, however, the same research topic be applied to Portuguese colonies (Angola)?

Other of the vertices of this revision triangle, it is the ivory; which was one of the top products in Portuguese demand from Africa and Asia, was primarily sought for its work for artistic purposes. In the sixteenth century, the Sultanates and Asia had the predominance of this traffic, a trend that in the seventeenth century changes to Africa. Demand for this good in Congo, Benin, with regard to Africa; and in Asia: India; Ceylon; China and Japan, will have a diversified demand, but corresponding to a specific market. About this subject many essays, papers, thesis have been written in Art history. Thus, its more plausible to this essay, to dig upon the most relevant texts about ivory and its economical study's. A characteristic prior to the XIX century, it is the reduced quantity of know sources related to the object in study [13]. The pioneering work of Harvey M. Feinberg and Marion Johnson, which attempts to provide a statistical projection for late seventeenth to eighteenth century ivory traffic in Senegal, it is an example of it. Within this academicals problem, both authors point out as one of the main complications the sources used, and the data that did not allow the elaboration of a complete, coherent series, which led to, for the case of Senegal, some extrapolation about the same data. Or, in the Portuguese colonial context, the works of João Batista Gimes Luís, who elaborates an interesting work, about Ivory providing a first synthesis with information about the importance of this good, within African societies; giving it as well a quantitative expression.

\section{Results: International Trade and Ivory Trade in the XVIII Century and Benguela Ivory Trade 1790 - 1810}

Beside the European conceptualization, the African kingdoms had their own way to identify the elephant. According to Marisa de Soares Carvalho, the term Ivory only referred to the raw prey coming from the Arabic term ivory meaning Elephant itself [14]. In Congo, it was called mene manzao (elephant tooth) and the youngster's moana monzau that means Elephant son [15]. The Ambundos called this species zamba (nzamba, onjamba, njamba) while the Muxicongos called them nzau [15]. This nomenclature given to elephant, that associated the species with ivory, raises the question is it possible to determinate the number of elephants killed from the collected ivory? Due to the absence of quantitative information related to the elephant in the official sources, alternative forms of determinate the existence population must be found. In the absence of direct statistical data, ivory is - due to be extracted from the elephant - the most credible option. One of the main difficulties pointed out by Harvey M. Feinberg and Marin Johnson was the deficiency of concrete quantitative data related to Ivory commercialization [16].One of the recurrent problems, is how the numerical information is displayed in the consulted sources. In the process of information recoil, they observed that ivory records in Dutch and British sources were priority described in ibs and pounds. If those data with that presented list it is useful in trade, it is not operatory in achieve the accurate numbers of elephants killed. The Portuguese document in A.H.U and in ANTT/Torre do Tombo provides also that information, but as well the number of tusks. Prior to the impact on elephant population, the definition of the quantity of tusks it is in order; due 
being the factor behind their demand and killing. In the opinion of Doran H. Ross the depredation of the elephant for ivory, was a long millennial process that reach its peak in the XIX and in the XX century [17].Another question that strengthens that perspective, providing the motive, it is the quality of the ivory extracted from the different species. The Asian Elephant and the bush elephant's tusks are considered hard, while the savannah elephants are considered soft and easier to work [16].

Table 1. Ivory Tusks collected in Benguela (1791 - 1810)

\begin{tabular}{|c|c|}
\hline \multicolumn{2}{|c|}{ Ivory tusks collected in Benguela $(1791-1810)$} \\
\hline Years & Benguela \\
\hline 1791 & 1388 \\
\hline 1792 & 1998 \\
\hline 1793 & 1207 \\
\hline 1795 & 2366 \\
\hline 1796 & 5472 \\
\hline 1797 & 1054 \\
\hline 1798 & 860 \\
\hline 1801 & 1213 \\
\hline 1802 & 1368 \\
\hline 1803 & 1368 \\
\hline 1805 & 0 \\
\hline 1807 & 3342 \\
\hline 1808 & 1052 \\
\hline 1809 & 1141 \\
\hline 1810 & 0 \\
\hline Total & 23829 \\
\hline
\end{tabular}

Sources: A.H.U, Conselho Ultramarino, Angola, Avulsos, Caixa 76, doc $\mathrm{n}^{\circ}$ 17; A.H.U, Conselho Ultramarino, Angola, Avulsos, Caixa 78, doc n 17, 23 - 01 - 1793; A.H.U, Conselho Ultramarino, Angola, Avulsos, Caixa 78, doc $\mathrm{n}^{\circ} 23,07-02-1793$; A.H.U, Conselho Ultramarino, Angola, Avulsos, Caixa 79, doc $\mathrm{n}^{\circ}$ 67, 1793; A.H.U, Conselho Ultramarino, Angola, Avulsos, Caixa 80, doc no 8, 19-01-1794; ; A.H.U, Conselho Ultramarino, Angola, Avulsos, Caixa 80, doc n⿳⺈ 21, 03 - 03 1794; A.H.U, Conselho Ultramarino, Angola, Avulsos, Caixa 80, doc n ${ }^{\circ}$ 28, 14 - 03 - 1794; A.H.U, Conselho Ultramarino, Angola, Avulsos, Caixa 81, doc $\mathrm{n}^{\circ}$ 5, 20 - 01 - 1795; A.H.U, Conselho Ultramarino, Angola, Avulsos, Caixa 83, doc no 41, 13 - 04 - 1796; A.H.U, Conselho Ultramarino, Angola, Avulsos, Caixa 84, doc no $13,23-01-1796$ A.H.U, Conselho Ultramarino, Angola, Avulsos, Caixa 85, doc n⿳⺈ 28, 07 - 03 - 1797; A.H.U, Conselho Ultramarino, Angola, Avulsos, Caixa 87, doc $\mathrm{n}^{\circ} 51$ B, 18 - 03 1798; A.H.U, Conselho Ultramarino, Angola, Avulsos, Caixa $\mathrm{N}^{\circ} 89$, doc. $\mathrm{N}^{\circ}$ 85, 1798; A.H.U, Conselho Ultramarino, Angola, Avulsos, Caixa No 105, doc $\mathrm{n}^{\circ}$ 20, 09 - 10 - 1802; A.H.U, Conselho Ultramarino, Angola, Avulsos, Caixa No 119, doc no 1, 14-01 - 1808; A.H.U, Conselho Ultramarino, Angola, Avulsos, Caixa No 120 , $\operatorname{doc}^{\circ}$ 1, 1-01-1809; A.H.U, Conselho Ultramarino, Angola, Avulsos, Caixa $\mathrm{N}^{\circ} 121 \mathrm{~A}, \operatorname{doc} \mathrm{n}^{\circ} 32,1810$. Fontes: Conselho Ultramarino, Angola, Avulsos, Caixa 84, doc no 13, 23 - 01 - 1796; Conselho Ultramarino, Angola, Avulsos, Caixa 85, doc no 28, 07 - 03 - 1797; Conselho Ultramarino, Angola, Avulsos, Caixa 87, doc no 51 B, 18 - 03 1798; Conselho Ultramarino, Angola, Avulsos, Caixa $\mathrm{N}^{\circ}$ 89, doc. $\mathrm{N}^{\circ}$ 85, 1798 ; Conselho Ultramarino, Angola, Avulsos, Caixa No 105, doc no 20, 09 - 10 $-1802$

Regarding Portuguese historiography about the traffic of this good, as indicated by João Batista Gimes Luis, at the end of the eighteenth century being exported, from 1792 1825, around 56992 ivory tusks, [18]. The archive data related to Benguela, from A.H.U, provides a very different scenario. In 1791 about 1388 tusks were sent, which correspond to about $8 \%$ of the total; while in 1792 around 1998 tusks were sent, equivalent to about $12 \%$, what corresponds to a $4 \%$ increase. By 1793 there are about 1207 tusks sent, which is equivalent to about $7 \%$ to a decrease of 5\%; whereas for 1795 there is a shipment of 2366 ivory prey, which is $15 \%$, which is a percentage increase of $8 \%$; in 1796 it reached 5472 tusks ,equivalent to about 35\%, and an increase of about 15\%. From 1797 onwards, there has been a drastic breakdown of ivory to 1054 tusks, $6 \%$ of the total, a drop of about $29 \%$; for 1798 there is a further decline to the 860 points, which is about $5 \%$ of the total and a decrease of $1 \%$ (table 1and Graph 1 ).

\section{Ivory tusks colected in Benguela (1791 - 1810)}

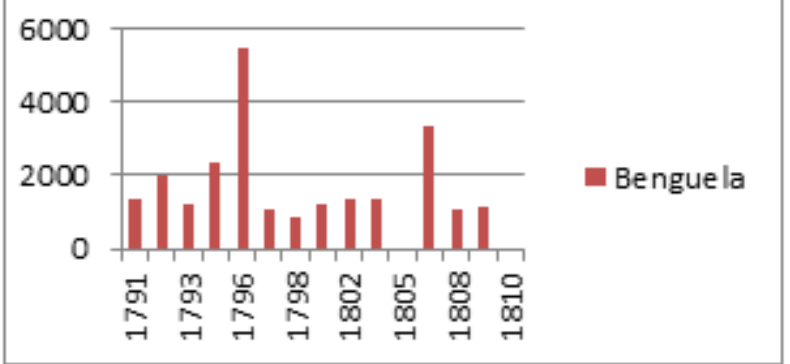

Sources: A.H.U, Conselho Ultramarino, Angola, Avulsos, Caixa 76, doc $\mathrm{n}^{\circ}$ 17; A.H.U, Conselho Ultramarino, Angola, Avulsos, Caixa 78, doc $\mathrm{n}^{\circ}$ 17, 23 - 01 - 1793; A.H.U, Conselho Ultramarino, Angola, Avulsos, Caixa 78, doc n ${ }^{\circ} 23,07-02-1793$; A.H.U, Conselho Ultramarino, Angola, Avulsos, Caixa 79, doc $\mathrm{n}^{\circ}$ 67, 1793; A.H.U, Conselho Ultramarino, Angola, Avulsos, Caixa 80, doc no 8, 19-01-1794; ; A.H.U, Conselho Ultramarino, Angola, Avulsos, Caixa 80, doc no 21, $03-03-$ 1794; A.H.U, Conselho Ultramarino, Angola, Avulsos, Caixa 80, doc no 28, 14 - 03 - 1794; A.H.U, Conselho Ultramarino, Angola, Avulsos, Caixa 81, doc $\mathrm{n}^{\circ}$ 5, 20 - 01 - 1795; A.H.U, Conselho Ultramarino, Angola, Avulsos, Caixa 83, doc no 41, 13 - 04 - 1796; A.H.U, Conselho Ultramarino, Angola, Avulsos, Caixa 84, doc no 13, 23 - 01 - 1796; A.H.U, Conselho Ultramarino, Angola, Avulsos, Caixa 85, doc $n^{\circ} 28,07$ - 03 - 1797; A.H.U, Conselho Ultramarino, Angola, Avulsos, Caixa 87, doc $n^{\circ} 51$ B, 18 - 03 1798; A.H.U, Conselho Ultramarino, Angola, Avulsos, Caixa $\mathrm{N}^{\circ}$ 89, doc. $\mathrm{N}^{\circ}$ 85, 1798; A.H.U, Conselho Ultramarino, Angola, Avulsos, Caixa $N^{\circ} 105$, doc no 20, 09 - 10 - 1802; A.H.U, Conselho Ultramarino, Angola, Avulsos, Caixa No 119 , doc no $1,14-01$ - 1808; A.H.U, Conselho Ultramarino, Angola, Avulsos, Caixa No 120, doc $n^{\circ}$ 1, 1 - 01 - 1809; A.H.U, Conselho Ultramarino, Angola, Avulsos, Caixa $\mathrm{N}^{\circ} 121 \mathrm{~A}, \operatorname{doc}^{\circ} 32,1810$. Fontes: Conselho Ultramarino, Angola, Avulsos, Caixa 84, doc n ${ }^{\circ} 13,23-01$ - 1796; Conselho Ultramarino, Angola, Avulsos, Caixa 85, doc no 28, 07 - 03 - 1797; Conselho Ultramarino, Angola, Avulsos, Caixa 87, doc no 51 B, 18 - 03 1798; Conselho Ultramarino, Angola, Avulsos, Caixa No 89, doc. $\mathrm{N}^{\circ} 85,1798$; Conselho Ultramarino, Angola, Avulsos, Caixa N ${ }^{\circ} 105$, doc n⿳⿲丶丶㇒一 $20,09-10$ -1802 .

Graph 1. Ivory Tusks collected in Benguela (1791-1810)

Provided the number of collected tusks let us embark on an academic journey, to determinate the number of elephants killed. With that intention I invite you to accompany me, through the logic that certified the establishment of that quantitative universe. An Elephant, unless he as lost it or it is much damaged, has two Ivory tusks. Dividing the total number of tusks by two, permit us to achieve the total number of elephants killed within the 
period where available documentation permit us to research. One other question would this formula permit the calculation of the mortality rates of elephant population in absolute terms? The calculation of mortality rates within a population consists in division of the totality of elements of a species with the totality of the population [19]. There are estimations that indicate that the Elephant Population could have reached for this period about 28 million elements [20].Estimations, however, are not concrete data what inhibits us (for the established chronology), to determinate the mortality of the species population in study; due to the inexistence of information about the total population in that area. To possess that data it would be necessary archeological field work, that would provided us with fossil registers of the period in study. In spite of not accomplish the totality of the mortality rate, this calculation allowed us to determinate the total account of elephants killed, in Portuguese colonial context, in XVIII century Benguela.

\section{Ivory Tusks: $2=\mathrm{N}^{\circ}$ of Elephants Killed.}

Established the ivory records for the period in study, and the method that will be used to determinate the number of elephants killed, let us exercise that same theory in practical terms. Nevertheless, before we begin the statistical exercise, some words about the species that inhabited those regions must be established. Until the beginning of the $\mathrm{XX}$ century it was considered the existence of one species of Elephant in Africa, the African elephant: (Loxodonta Africana).Nevertheless, in the dawn of the mentioned century this sub-species was identified by Paul Mastchie that named him forest elephant (Loxodonta Cyclotis). In the eminence of being two sub types of the same species, we shall make the distinction between both. The first, the largest in its kind on the African continent, has a height of up to 6 - 7.5; and having a withers height of about 240 to $360 \mathrm{~cm}$ and a weight of about $6-7$ tons. Gestation lasts about 22 months with longevity of about 60 - 70 years [21] [22]. The second, which is the smallest of the sub-species, possess a maximum weight of 4 tones, and a height in the withers from 245 to $285 \mathrm{~cm}$; having, like the Asian counterpart, five hooves on the front paws and four on the hind legs. Another variance it is associated to their habitat. The (Loxodonta Africana) habitat is the savannah regions of Africa; while the Loxodonta Cyclotis lives in the regions of the Guinea forest to the Congo rain forest [22] [23]. About the habitat of both species, I will explore better in further chapter of this essay. However, it was of importance to proceed to a small identification, so it may be possible to classify the species that we are talking in the statistical universe about to be elaborated. Other question in order, it is the geographical characteristics of Benguela. The region in study, it is surrounded in south by the Namibia desert, in the littoral there are some plains; in the inlands the geographical relief it is characterized by savannah and mountains. Accessing the inlands (in the course of Bemga), the physical geography consists in the plateau of Huambo/Bié where there are rich Savannah regions; which implicates that(according to the features of that region)the dominant species is the Loxodanta Africana. Had defined the regions, I invite you all to accompany me in the process of establishing the numbers of elements of the mentioned species that were killed. Resuming the statistical problems, whenever the results provided number with decimal houses, I've converted them in a fractional number. The criteria by which that procedure was effectuated was not only due to mathematical rules, but also due that the sources consulted make no mention to any broken our any half tusk.

Table 2. $\mathrm{N}^{\mathrm{o}}$ off Elephants hunted for Ivory extraction

\begin{tabular}{|c|c|}
\hline Years & $\mathrm{N}^{\mathrm{o}}$ off Elephants shots for Ivory extraction \\
\hline 1791 & 694 \\
\hline 1792 & 999 \\
\hline 1793 & 604 \\
\hline 1795 & 1183 \\
\hline 1796 & 2736 \\
\hline 1797 & 527 \\
\hline 1798 & 430 \\
\hline 1801 & 607 \\
\hline 1802 & 684 \\
\hline 1803 & 684 \\
\hline 1807 & 1671 \\
\hline 1808 & 526 \\
\hline 1809 & 571 \\
\hline 1810 & 0 \\
\hline Total & 11915 \\
\hline
\end{tabular}

Sources: Fontes: A.H.U, Conselho Ultramarino, Angola, Avulsos, Caixa 76, doc n ${ }^{\circ}$ 17; A.H.U, Conselho Ultramarino, Angola, Avulsos, Caixa 78, doc no 17, $23-01-1793$; A.H.U, Conselho Ultramarino, Angola, Avulsos, Caixa 78, doc no 23, $07-02-1793$; A.H.U, Conselho Ultramarino, Angola, Avulsos, Caixa 79, doc no 67, 1793; A.H.U, Conselho Ultramarino, Angola, Avulsos, Caixa 80, doc $\mathrm{n}^{\circ}$, 19-01-1794; ; A.H.U, Conselho Ultramarino, Angola, Avulsos, Caixa 80, doc $n^{\circ}$ 21, $03-03$ - 1794; A.H.U, Conselho Ultramarino, Angola, Avulsos, Caixa 80, doc no 28, $14-03$ - 1794; A.H.U, Conselho Ultramarino, Angola, Avulsos, Caixa 81, doc no 5, $20-01$ - 1795; A.H.U, Conselho Ultramarino, Angola, Avulsos, Caixa 83, doc no $41,13-04-$ 1796;A.H.U, Conselho Ultramarino, Angola, Avulsos, Caixa 84, doc $\mathrm{n}^{\circ}$ 13, 23 - 01 - 1796; A.H.U, Conselho Ultramarino, Angola, Avulsos, Caixa 85, doc no 28, 07 - 03 - 1797; A.H.U, Conselho Ultramarino, Angola, Avulsos, Caixa 87, doc no 51 B, $18-03$ 1798; A.H.U, Conselho Ultramarino, Angola, Avulsos, Caixa N ${ }^{\circ} 89$, doc. $\mathrm{N}^{\circ} 85,1798$; A.H.U, Conselho Ultramarino, Angola, Avulsos, Caixa No 105, doc no 20, 09 - 10 - 1802; A.H.U, Conselho Ultramarino, Angola, Avulsos, Caixa No 119, $\operatorname{doc}^{\circ}$ 1, $14-01$ - 1808; A.H.U, Conselho Ultramarino, Angola, Avulsos, Caixa $\mathrm{N}^{\circ} 120$, doc $\mathrm{n}^{\mathrm{o}} 1,1-01-1809$; A.H.U, Conselho Ultramarino, Angola, Avulsos, Caixa No 121 A, doc n ${ }^{\circ} 32,1810$.

The data recoiled from the A.H.U in the documents of Benguela, permitted to determinate 11915 elephants of the species Loxodonta Africana that were hunted. In a general supervise the scenario of depredation does not present himself very regular being documented the following 
tendency: in 1791, about 694 ( $6 \%$ of the total); in 1792, a numeral of 999 ( $8 \%$ of the total), more 305 elephants killed then the previous year and an percentage increase of $2 \%$; 1793, about 604 (5\%), a decrease of 395 specimens hunted and a break of $3 \%$; by the year 1795,1183 preyed $(10 \%)$ extra 579 slaughtered specimen increasing 5\% comparing with the previous year; 1796, around 2736 $(23 \%)$ additional 1553 elephants killed and an intensification of $13 \% ; 1797,527,(4 \%$ of the total ) less 2209 then the preceding year, corresponding to a diminution of $21 \% ; 1798,430$ preyed ( $3 \%$ of the total), minus 97 and $1 \%$ decline ; 1801, 607, (5\%) an increase of 177 elements, with $2 \%$ growth; in 1802 and 1803 (6\% for both years), with a quantity of 684 elephants hunted in both years, a stabilization in 77 further then in 1801 and $1 \%$ above the same year; 1807, 1671, more 987 specimens preyed, (14\% of the total) and $9 \%$ ascent in comparison with $1806 / 1807 ; 1808,526$ ( $4 \%$ of the total), less 1145 specimen's shot then the prior year representing $10 \%$ minus; 1809, $571(5 \%)$ an increase of 45 elephants killed ascending $1 \%$ from 1809 (table 2; graph 2 ).

\section{№ off Elephants shots for Ivory extraction}

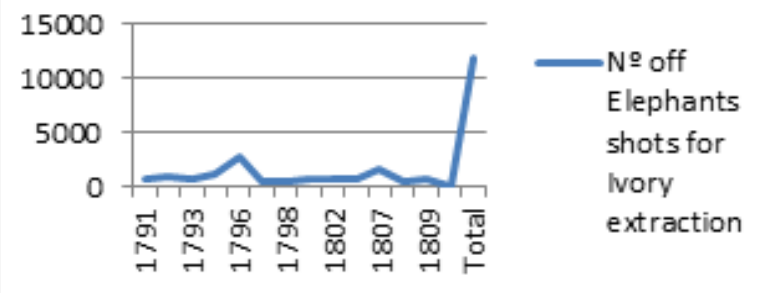

Sources: Fontes: A.H.U, Conselho Ultramarino, Angola, Avulsos, Caixa 76, doc $\mathrm{n}^{\circ}$ 17; A.H.U, Conselho Ultramarino, Angola, Avulsos, Caixa 78, doc $\mathrm{n}^{\circ}$ 17, 23 - 01 - 1793; A.H.U, Conselho Ultramarino, Angola, Avulsos, Caixa 78, doc $\mathrm{n}^{\circ}$ 23, 07 - 02 - 1793; A.H.U, Conselho Ultramarino, Angola, Avulsos, Caixa 79, doc no 67, 1793; A.H.U, Conselho Ultramarino, Angola, Avulsos, Caixa 80, doc $\mathrm{n}^{\circ} 8$, 19-01-1794; ; A.H.U, Conselho Ultramarino, Angola, Avulsos, Caixa 80, doc no 21, $03-03$ - 1794; A.H.U, Conselho Ultramarino, Angola, Avulsos, Caixa 80, doc no 28, $14-03-1794$; A.H.U, Conselho Ultramarino, Angola, Avulsos, Caixa 81, doc no 5, 20 - 01 - 1795; A.H.U, Conselho Ultramarino, Angola, Avulsos, Caixa 83, doc no 41, 13 - 04 1796; A.H.U, Conselho Ultramarino, Angola, Avulsos, Caixa 84, doc n 13, 23 - 01 - 1796; A.H.U, Conselho Ultramarino, Angola, Avulsos, Caixa 85, doc $\mathrm{n}^{\circ}$ 28, 07 - 03 - 1797; A.H.U, Conselho Ultramarino, Angola, Avulsos, Caixa 87, doc no 51 B, $18-03$ 1798; A.H.U, Conselho Ultramarino, Angola, Avulsos, Caixa $\mathrm{N}^{\circ} 89$, doc. $\mathrm{N}^{\circ} 85,1798$; A.H.U, Conselho Ultramarino, Angola, Avulsos, Caixa No 105, doc no 20, $09-10$

- 1802; A.H.U, Conselho Ultramarino, Angola, Avulsos, Caixa № 119 $\operatorname{doc}^{\circ}$ 1, $14-01-1808$; A.H.U, Conselho Ultramarino, Angola, Avulsos, Caixa $\mathrm{N}^{\circ} 120$, doc $\mathrm{n}^{\circ} 1,1-01-1809$; A.H.U, Conselho Ultramarino, Angola, Avulsos, Caixa No $121 \mathrm{~A}, \operatorname{doc} \mathrm{n}^{\circ} 32,1810$.

Graph 2. $\mathrm{N}^{\mathrm{o}}$ off Elephants Shots for Ivory Extraction

If the data present in the documentation of the A.H.U, permitted the establishment of official number of killed pachyderms' other operations were possible through the utilization of the documentation of casa da India. Beside absolute values, like the ones established based in the documentation of A.H.U, it was possible to divide the same documental information in different tusk size and weight: Leys; Meao and Miudo. These different categories of ivory, more than only a mere unit of weight, also indicate the age that the pachyderms would have at the time of death. Ley's would be for elephants in adulthood; while Meao corresponded to rather adolescent pachyderms; and Miudo referred to infant specimens.

Other question is the provenience of the Ivory. In this case the source does not distinguish whether they came from the East or West African coast, from which Asian ivory also passed in is way to Lisbon, neither we could find information about to establish the difference of commercialized ivory providence from the distended areas. The Balança commercial do reino, has information about tusks that came from Angola expressed in weight category and in Libras; information not available the Asian colonial trade. The source typology had as main objective the record of Portuguese trade, with other nations, and with its colonial world, which implies if that register it is not present; that the mentioned good was not being transitioned from Asia to Portugal in that period. Nevertheless, makes it highly probable that the great source of ivory, for Portuguese XVIII century Ivory trade, was Africa. According to Martha Chaikill, the great exploration of ivory by western overseas powers begin in the XVII century, due to western commercial rivalry; extended, in the XVIII century, beside Europe, to India and China [24]. Has a consequence of that demand the preeminence of African Ivory in the mid eighteen centuries, may be a consequence of Asian elephant's population decline [24]. In that scenario and due to the absence of records related to Asian tusks, we may safely consider that the record in the consulted sources was exclusively about the tusks traded from Africa. To establish the elephant sub-type, we used the Portuguese presence in West and Easter coast of Africa to determinate. In the period of study, Portuguese were mainly located in Mozambique; what reduced their access to a species that lives in the inlands of that region that corresponds to the Loxodonta Africana. Other question to identify the origin of the ivory, is the commercial routes from where they were sent to Portugal. In the case of Angola, the merchant Atlantic routes used (having the reference of the departure from the ports of Brazil), are consisting with slave trade routes from the mentioned region to Portuguese America. Summoning these facts permit us to conclude the African origin of the ivory, and specifically from Angola, besides the species from where was extracted. To perform this calculation we used, in a first stage, the elaborated formula to identify the general population of elephants that were killed; and, in a second phase, we used a rule of three to determinate the percentage of elephants, in their age rank, that were hunted.

Operating that process, we achieved the present results: 12739 elephants killed; of which 4436 were adult elephants; 2851 were in their adolescence and 5452 were mere cubs. Regarding the number of adult elephants killed, we 
establish this trend: in 1796,714 , about $16 \%$ of the total; in 1798,868 , a $4 \%$ growth to $20 \%$ and a difference of 154 elephants to the previous year; to $1799,13 \%$, a decrease from $7 \%$ from a total of 330 pachyderms, that represents less 538 elephants hunted; in 1802, consisting in 515 adults killed, an increase of 185 elephants and of $4 \%$ to $11 \%$; In 1804 there is a further increase of $5 \%$ corresponding to more 213 adult elephants preyed, reaching 16\% from a total of 728 slaughtered elephants; in 1805 there was a decrease of 194 hunted elephants reaching 534 elements preyed, representing a drop of $4 \%$ to $12 \%$; by 1806 there was a $5 \%$ drop, with the number of adult elephants killed reaching 311 less 223 then the previous year; and for the year 1807 there is an increase of 3\%, reaching $10 \%$ from a total of 436 slaughtered elephants, an increase of 125 elements in comparison with the previous year (Table $3 \mathrm{~A}$ ).

Beside the adults a significant number of elephants aged in adolescence were slaughtered related with the ivory demand, being determinate the following tendency: 1796 registers 564 killing, equivalent to $20 \%$ of the total; 1798 , about 658 , an increase of 94 elephants, as well an increase of $3 \%$ to $23 \%$ in percentage weight; in 1799 was accounted 222 dead elephants, a drop of $16 \%$ to $7 \%$ as well of 436 pachyderms in numerical terms; by 1802 there was an increase of $4 \%$ to $11 \%$ of the total, reaching 315 elephants slaughtered intensifying 93 plus compared with the previous year; in relation to 1804 we observe a further increase of 93 elephants, to a total of 408 , corresponding to an increase of $3 \%$ to $14 \%$ of the total elephants killed; referring to 1805 , there was a $5 \%$ drop to $9 \%$ corresponding in numerical dimension to a total 281 , minus 125 slaughtered elephants; in 1806 there were about 179 elephants, a drop in the order of 127 and a decrease of $3 \%$ to $6 \%$; and, by 1807 , about 224 elephants, an increase of 45 pachyderms and a percentage increase of $2 \%$ to $8 \%$ (Table 3 A).

And finally the patterns established related to elephants killed in childhood, present us the following numerical dimension: in 1796,1106 , corresponding to about $20 \%$ of the total; in 1798 there was an increase of $8 \%$ to $28 \%$, corresponding to 1544 hunted elements, an increase of 438 dead elephants; for 1799 there was a decrease of $21 \%$ to $7 \%$ resulting from 388 cubs killed, less 1156 than in the previous year; compared to 1802 there is an increase of $3 \%$ to $10 \%$, resulting from 520 dead elephants an increase of 132 hunted cubs; for 1804 was calculated a killing, in numerical terms, of 620 cubs, a difference of about 100 related to the previous year, corresponding to a percentage increase of $1 \%$ in a total of $11 \% ; 1805$, there was a slight increase for 630 hunted cubs, plus 10 , equivalent to a percentage increase of $11 \%$ the same as the previous year; for 1806 there is a $6 \%$ fall, registering $5 \%$, resulting of 276 cubs killed less 354 then in the previous year; and in the final year, 1807, we calculated 368 elephant cubs, an increase of $1 \%$ to $6 \%$ corresponding to 92 elephants plus then in the previous year (table $3 \mathrm{~B}$ ). These elephants should have from three years or more, because the elephant tusks only start to grow when he reaches that age.

Table 3 A. Elephants Shot between 1796 - 1807 according the calculation over the data of da entrada do Marfim

\begin{tabular}{|c|c|c|}
\hline years & adult age & Adolescence \\
\hline 1796 & 714 & 564 \\
\hline 1798 & 868 & 658 \\
\hline 1799 & 330 & 222 \\
\hline 1802 & 515 & 315 \\
\hline 1804 & 728 & 408 \\
\hline 1805 & 534 & 281 \\
\hline 1806 & 311 & 179 \\
\hline 1807 & 436 & 224 \\
\hline Total & 4436 & 2851 \\
\hline
\end{tabular}

Table 3 B. Elephants Shot between 1796 - 1807 according the calculation over the data of da entrada do Marfim

\begin{tabular}{|c|c|c|}
\hline years & childhood & Total \\
\hline 1796 & 1106 & 2902 \\
\hline 1798 & 1544 & 3342 \\
\hline 1799 & 388 & 2187 \\
\hline 1802 & 520 & 2322 \\
\hline 1804 & 620 & 2424 \\
\hline 1805 & 630 & 2435 \\
\hline 1806 & 276 & 2082 \\
\hline 1807 & 368 & 2175 \\
\hline Total & 5452 & 12739 \\
\hline
\end{tabular}

Sources: ANTT/TORRE DO TOMBO, Alfândegas de Lisboa, Casa da Índia, Entrada de Marfim, liv. 1541; ANTT/TORRE DO TOMBO, Alfândegas de Lisboa, Casa da Índia, Entrada de Marfim, liv. 1542; ANTT/TORRE DO TOMBO, Alfândegas de Lisboa, Casa da Índia, Entrada de Marfim, liv. 1543; ANTT/TORRE DO TOMBO, Alfândegas de Lisboa, Casa da India, Entrada de Marfim, liv. 1544; ANTT/TORRE DO TOMBO, Alfândegas de Lisboa, Casa da Índia, Entrada de Marfim, liv. 1538; ANTT/TORRE DO TOMBO, Alfândegas de Lisboa, Casa da India, Entrada de Marfim, liv. 1539; ANTT/TORRE DO TOMBO, Alfândegas de Lisboa, Casa da Índia, Entrada de Marfim, liv. 1540;

About the problematic of mortality, it is not possible to determinate the impact of the species hunting in elephant population. Another indication, however, concerns about the birth and population renewal, in which is depredation had the impact already established. The concept of birth is considered the capacity of a species to grow, evolving the birth and grow of their individual elements. In this case, it can be applicable, also, the concept of ecological birth, that surveys the growing of a population in adversity opposing real or natural conditions [9]. In this case, how deep, by a real condition, was the impact of the hunting in statistical terms? Elephant population as a regeneration problem due the gestation period duration 22 months ( 2 years) giving birth to a single cub, which implies a very reduced capacity of the population to be renewed. To establish the potential impact on population the data recoiled allowed considering, in an age scale, the generation of elephants that was more affected by ivory demand. Calculation of the recoiled data, permit us to establish the following trend: $43 \%$ of depredation affected the elephant cubs; while $35 \%$ affected 
adults' population, and $22 \%$ adolescent elephants. The trend established by the sources indicate, that the highest and the lowest of the age pyramid, was being deeply affected in $78 \%$ of the totality of the depredation. The numbers and percentage permit to evaluate a deep impact on the population in age of reproduction, and in age of develop. The reduction in young age meant that the population would not have members in adulthood in age of reproduction, while the same phenomena in adult meant reduction of population in age of reproduction. In a more direct impact, it is one of the main causes of the reduced shortage of elements in adolescence, because there were not many elements reaching that life's phase and therefore being hunted.

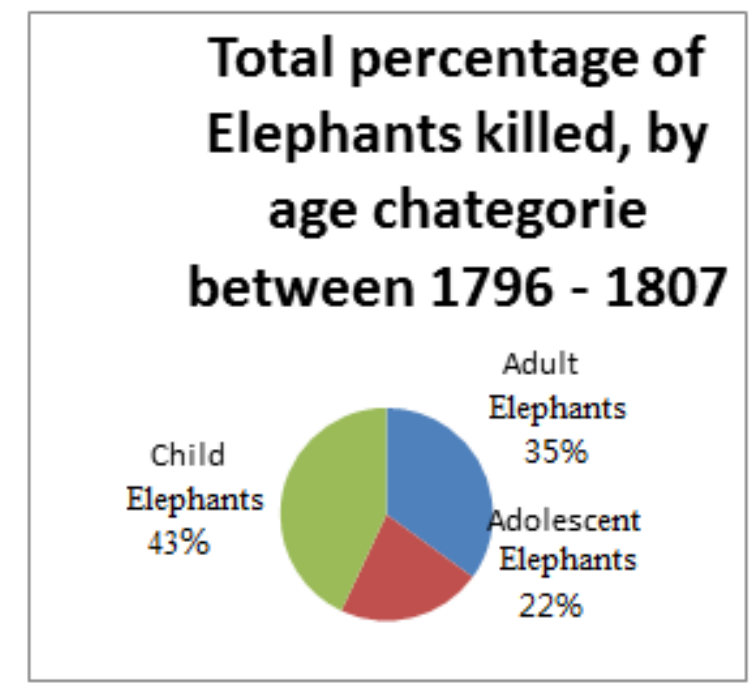

Graph 3. Total Percentage of Elephants Killed by age Category in $1796-1807$

\subsection{The XVI - XVIII Century Sources and Reports about the Elephant in Angola and Benguela}

The numbers and statistics of the previous point raise the academic question, what was the impact of the ivory demand, off the different percentage values, in Elephant habitat in Angola? The statistical dimension, collected and worked, provide the number of elephants hunted in Angola. Some other estimative were developed for that period related to the total population of elephants, which enables the utilization of the appropriate formula; instead, the reduction of the presence in their habitat can indicate high rate mortality in a timeline of one hundred years. In that logic, it is necessary to define the regions where the research was possible to be effectuated. According to N. Thomas Hakanson, it's very unlikely to find sources about the Elephant habitat and its reduction, prior to the XIX century [13]. This theory makes me speculate if there is none other forms to research for information related to the Elephant? The written chronicles and documentation produced by Portuguese authorities associated to Angola, specifies a variety of information that it is not limited to political, economic and social questions that required the governor's attention. Other information was the descriptions about fauna and flora. Much of the information presented in the sources relate, not to the immense territory, that would be under Portuguese direct rule in the XX century, but to regions where Portuguese had military and merchant interests, or with whom had trading relation. Due to that circumstance the written documentation (both chronicles and manuscripts), provide more reliable sources offering references to elephants in the merchant circuits; related to ivory demand, and by association, providing some data about the species habitat. To establish the intended comparison, is required to search sources prior do the century in study, so we have a departing point of where elephants habited in Angola, comparing that information with the one present in XVIII century sources.

Other question, it is necessary, more than due to an erudition exercise, to identify the regions where the sources indicate that elephants were found. To begin with, some regions name could not be the same during the centuries, even from the XIX century to the XX century the name of the provinces do not have correspondence to the ancient name of the territories. Other question, one name can be used to identify different areas that did not had any geographical proximity. Relatively to the documental reference of elephants, we can trace some to early contacts of Portuguese with that area. For the XVI century, in some relações, there are some vague information (like in the relação from 1575 written by Garcia Simões about the second voyage of Paulo Dias Novais), where is indicated only that there were many elements of that species in the region [25]. Beside of that vague reference, other sources develop much more specific information about the space where elephants were present. Conferring with the Relação do Reino do Congo e das Regiões Circunvizinhas from Filipo Pigafeta and Duarte Lopes, written in 1591, there were large populations of Elephants in the region of Loango (north of Congo), in the region of Bemba and in another territory named Cassange: "The animals that are found in this region are first elephants, which are born in the whole of Congo but mainly in the region of Bamba, because it is more abundant of jungles, pastures and water." "Where it was said by Lord Duarte to have seen, going from Caçanze to Loanda, in a small and fresh valley, a number of 100 (usually walking in herds like the cows and the camels and similar gentle animals, not only by the lions and other ferocious animals) between big and small that has then turned. Now so abundant with ivory those regions, considered because, being born in those places great multitude of elephants and not making first case of such matter" [15].The second reference indicate a large population of elephants in the region of Cassange, which constitutes a geographical problem. To define the elephant habitat, it is necessary to define what region was the Kassange reported in the sources. The region with that 
nomenclature was a political reality of the XVII century not being know any reference previous to that century unless in the chronicle of Duarte Lopes. The designation corresponds to a XVII century political realm, part of a region that was situated between the rivers Kamba, Lutoa and Kwango founded by Mbangala Kulaxingo in 1630 located in the current province of Malange and part of Lunda Norte [16]. The chronology of the foundation of that reality is posterior to the presence, and life of Duarte Lopes in that region, what impossibilities the hypothesis of being the same realm. The region in question is designated being the land of the Mani Kassange placed in the continuity of Bamba [15]. The domains of this lord, as the others that where under the authority of the Manibamba, remained political regions established in the littoral lands [15]. Other question related to his geographic location, according with a map elaborated through the source in question, was placed east of Luanda between the rivers Bengo and Kwanza, nearer the Bengo, between Luanda and Anzele (map 1). The domains of the Cassange, XVII century Kingdom was inland, very far from the ocean and rainforest zone. Beside the identification of the region, as a political construction, it is necessary to determinate is physical characteristics. The region mentioned in the chronicle distinct from the space it occupied in the XVII century, not only as a political space, but also like a different climate zone with subsequent specific fauna and flora. This XVI century establishment is, in the condition of continuity of Bamba, a region of rainforest clime; being described, the zone where Elephants were traced, with abundance of water and a fresh valley. That description is similar to rainforest flora, more common in the northern region of Angola where there is a landscape similar of Congo [26]. The regions from the north part from Luanda to the region of Cabinda, the flora it is characterized by tropical rain forest the typical habitat of the Loxondota Cyclotis. To strengthen this affirmation Duarte Lopes noted the physical characteristic of this species: "The ears are so large, rather than a broad, that of the largest that the Turks wear, long six palms, ovate in shape, narrowing to the shoulders at the tip." [15]. Those characteristics, specially the ears, are typical of forest elephant; what indicates it was the species living in the north of Angola. In present times, the forest elephant, has is habitat reduced to the north of Angola in Cabinda and in contemporary provinces of Zaire, Cabinda and Uige [23].According with the sources and map, in the XVI century, the elephant territory situated southern to Bengo (where the XVI century Kassange was placed) and in Kwanza Norte.

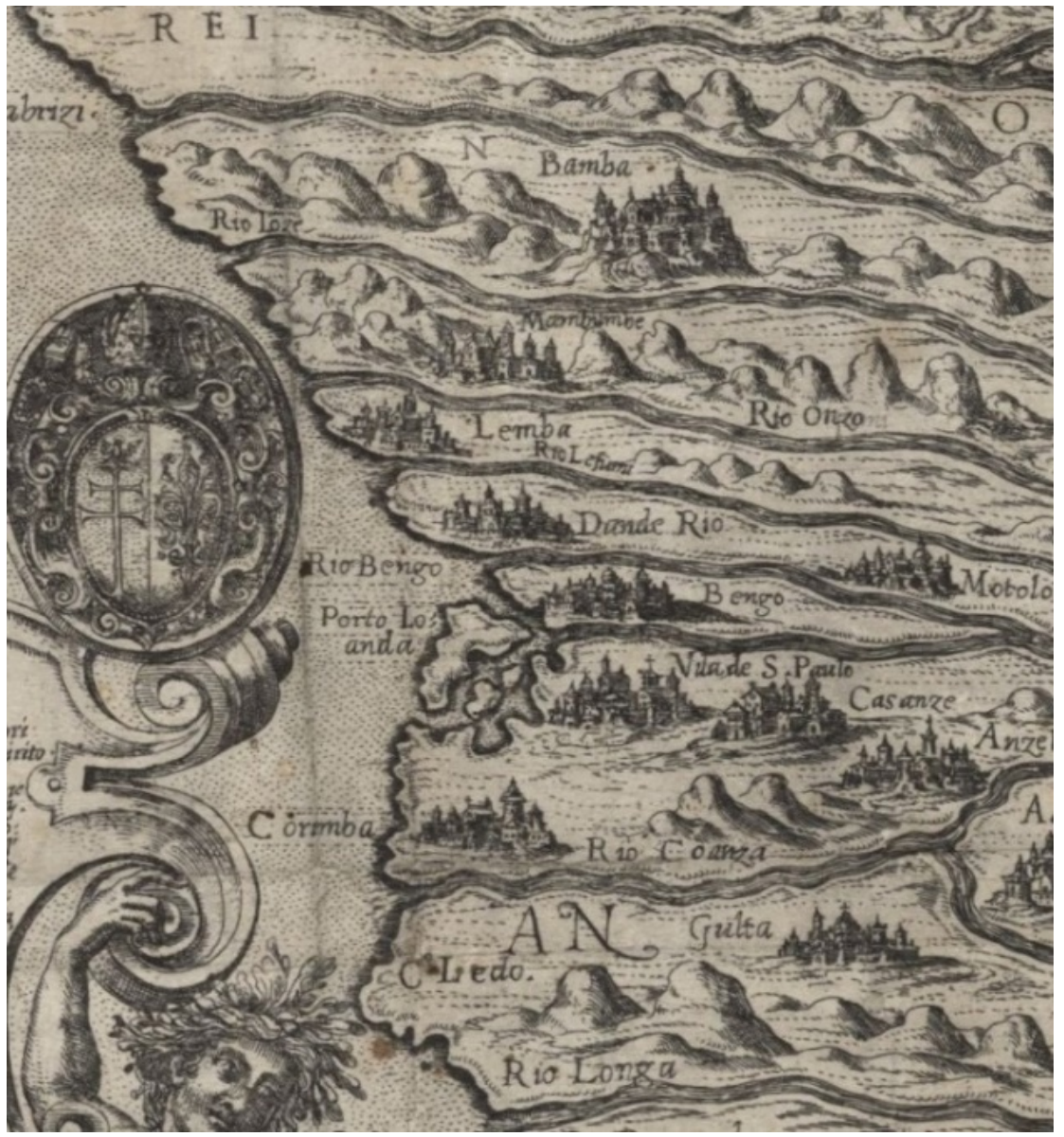

Source: Duarte Lopes \& Filipo Pigateffa, Relação do Reino do Congo, Lisbon, Agência Geral do Ultramar, 195

Map 1. Angola and Congo's map based in the description made by Duarte Lopes to Filipo Piagattefa with the location of XVI century Cassange 
To the end of the XVIII century and in the beginning of the XIX century, there are some sources that indicate the commercial networks that operated in Angola inlands; from where ivory was merchandise to Luanda and the elephant species lived: "already some small establishments or Dwellings for the parts of Certão, since at first still afraid little of the beaches. They depart: on the banks of the Bengo River and Dande were the first dwellings of this nature; meeting there, or waiting for the Blacks, who from above to this City, with their shipments of Ivory, Wax, or Slaves, would make their permutations with them into a better market with them, so as not to conflict with the more buyers as for those preferring to make contracts immediately in those parts, still to the detriment just because they avoid the delay and penalty of coming to the Capital" [27].

In consequence of the reduced general knowledge of Angola Geography, it is required to establish the regions to properly identify the presence of elephant populations. This region described by the source compasses the areas between the river Bengo and the Dande that were both northern boundaries of the dominions the Mani Kassange in the XVI century. Contraire to what was recorded to the mentioned century, the source quoted makes no mention to the Ivory coming from near of those rivers neither from neighbouring lands. Yet, it is declared that the merchants from the inlands arrived to the outposts in the designated merges; where preferred to negotiate their commodities instead of heading ivory, along other goods, to Luanda. About the elephant population, it was not mentioned any direct reference; unless the ivory trade, from where we will try to identify the location of elephants; only stating that it emanated from above that city making no specific reference to the exact space of origin. The reference to above the city, implies that the mentioned merchandise was being traded from north to the declared establishments. In spite of the absence of a specific geographical reference, some possibilities can be properly developed. From far north of the river Dengo may imply that it probably came from the region of Bamba, from where (since the XVI century), was reported an extensive population of Elephants. As stated prior in this point, the southern regions of that Kingdom of Congo's province corresponding to is fauna and floristic continuity. Other matter, more commercial, is if the merchants preferred to trade in those outposts the mentioned goods, it implies that they already made a long distance voyage to the merchant outposts. In virtue of that possibility, it explains the motive of their refusal to go to Luanda, and also strengthens the possibility of elephants were very far from where the outposts were located. The absence of allusions to elephant's population, and the reference from above, implicates that there were no populations of the pachyderm in the surrounding regions of Luanda. To strengthened that hypothesis is that in the XVI century there was a large population of Elephants in the territory of Mani Cassange (near 100), that was east and not very far from Luanda. Not being mentioned any trade made from surrounding regions, implies that those populations were not in that area; what implicates, as consequences of that absence, that the Ivory origins may be from Bamba and is whereabouts in the beginning of the XIX century. Other interesting question, related with the documents, when Ivory, or other goods, were traded in regions close to Portuguese establishments, the sources indicated is provenience from proximal regions; which isn't done in this case. In recent years, in the end of the civil war $(1974$ - 2004) some isolated herds were located in that region, and some others in Maiombe (Cabinda) [23]. In the XVIII Century there is no reference to forest elephant populations, in the area between the Bengo and Dande and in nearer regions from those rivers.

Beside the access to ivory and elephant population in the north, there is reference of accessing it from east through the merchant network of the river kwanza. Nevertheless, that same regions homes not the forest elephant, instead, the savannah elephant, that is the predominant species of Elephantidae in Angola. The second subspecies habited the littoral plains land, the northeast, the east, and in the southern half of this country [23]. To that specific area, the writings of Cadornega, provide some information about the fauna and ivory trade. In his chronicle he notes several episodes regarding encounters between elephants and humans, and also with other animal species. Due to the limitation in this article, it was chosen to focus mainly in description where the elephant habitat can be located in a long duration perspective to effectuate a coherent comparison with the objective to establish the species environment. An account characterizes the region of Muxima (that is at 20 leguas from Luanda), as a region with a large diversity (beside other species) of elephants herds, indicating their regularity in the margins of the Rio Kwanza: "And if there are those who hunt him with a shotgun, or he is curious, he kills in those areas many crested and Galician royal ducks and marrecose are in great quantity covering crown, making great laughter; and this abundance is to be found throughout all this navigation and above the broad banks of the meadows, all kinds of thick and thin bush hunting; there you see elephants" Beyond this reference, the author makes another one about a group in Kwanza river. [4]. "In this very place the ancients were counting, there had been something extravagant that succeeded her; and it was that coming from our part of Illamba, to pass this Coanza river to the Quissama band, some elephants by this time fogg"[4].

Both this passages place elephant population southeast of Luanda, in the course of the kwanza. The first exert mentions, on the course of mentioned river, a distance of twenty miles from Luanda locating them in the south shore of the kwanza north to Quissama; zones characterized by Gavazzi as savannah. The other mentioned regions Ilamba and Massangano locate both in the same area, being this 
last one a Portuguese outpost in the mentioned region. Those establishments were not much far from Luanda, what indicates that elephant populations where near from regions were Portuguese had effective presence. Due to the features of their landscape the dominant subspecies, reverse to the northern fauna, is the Loxodonta Africana. Was, however, the reality of that region similar in the XVIII/XIX century. To the end of the XVIII century and beginning of the XIX, some sources provide us some information about ivory. In the History of Angola of Elias Correia's, it is estimated that "although the deepness of the Sertão abounds of this kind, demanding the distance of the Capital, large number of porters, that increase by the daily expenses of the transport». To access the regions that sourced ivory, and therefore indicated elephant population, was very difficult, what legitimates the question; what was the Elephant habitat in the kwanza course? In a note of the author, beside the distance, he indicates the provenience of the ivory in Kassange (that is not the same geographical and political unit of the XVI, consequently I will aboard it more extensively during this chapter) and in the lands of Ginga; what implicates that the elephant populations were in a $702.23 \mathrm{~km}$ distance from Luanda [28]. Comparing with the sources of the final of the XVII century, there is none mention to ivory from the region of Quissama, and other regions of the fluvial shores of the kwanza for the preceding century. The lands of Ginga (XVII century Matamba that was the land under the authority of Rainha Ginga, and whose name may be used to designate that same region; currently situated in the Province of Angola named Malanje), was reachable through the river kwanza which was the main road to contact the Angola inlands. Regarding the identification of XVIII century kassange it was not the XVI century geographical and political realm. This designation denotes the political unity created by the Jagas (Imbangalas warriors - that were itinerant acting like mercenary war lords - that deserted the Portuguese military service in 1620), as the map clearly presents being in different geographical coordinates comparing with the original designation that was located in the littoral; while the XVIII century is placed in the inlands southeast from the lands of Matamba what is also visible due to the route to contact it (map 2, map 3.) Reverse to the one mentioned in the XVI century, that it's represented by the title of Manicassange, that acted as vassal of the Mani Kongo, the ruler of Congo, this kingdom had no relation neither any loyalty to Congo; being allied with who show them better conditions in war and spoils. Other distinction was in is fauna and flora, more diversified that the political realm of the XVI-century, characterized by jungle landscape. The XVII/XVIII century Kassange is occupied, in the contemporary times, by the Angola provinces of Lunda North and Malange, whom, possess two distinct climes: the tropical savannah, in the north; and the humid subtropical climate, in the south. The regional distinctions permit us not only, to determinate the reduction of Elephant habitat in this area, but, inclusively, determinate the exact elephant species. The region of Matamba, in the north and northeast, is dominated by rainforest landscape; while in the south (in the shores of the river kwanza) the dominant geographical characteristic is the savannah. Geographical feature that was recurrent through that river course, characteristically also of the north of Kassange, what placed elephant population in a quite specific area, characterized by the mentioned feature. From the XVII century to the XVIII, there is an undeniable retreat of elephant populations from zones near the shore to the inlands. In this case, due to the information provided by the commercial networks, the regions where Elephants lived, both in the north, and in the south of Luanda, were becoming further away to the north and to the south east of the Capital. 


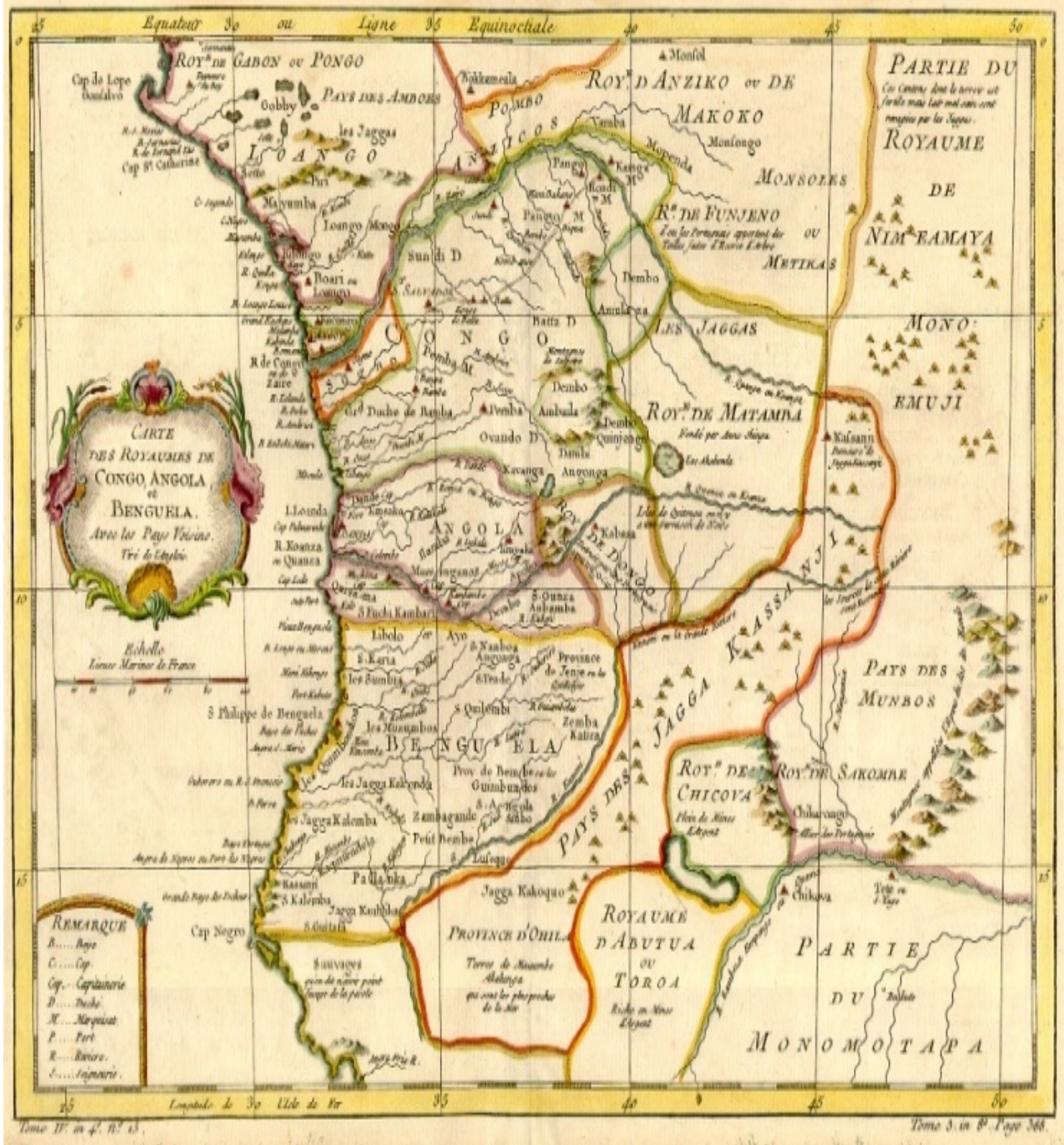

Source: Carte dês royaumes de Congo Angola et Benguela avec les pays voisins / tiré de l'anglois [par Bellin], 1757.

Map 2. Map of Angola in the XVIII century 


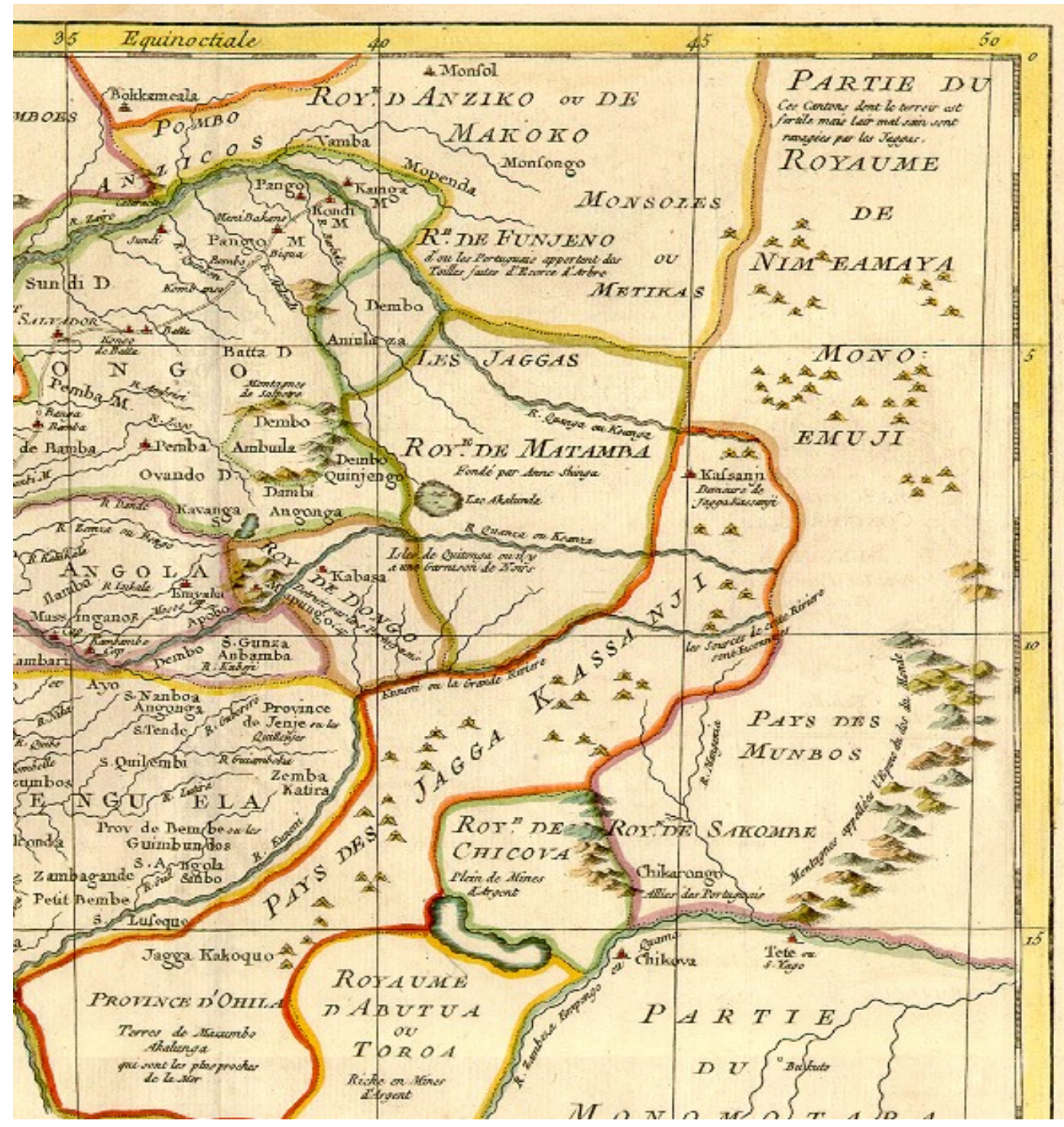

Source: Carte dês royaumes de Congo Angola et Benguela avec les pays voisins / tiré de l'anglais [par Bellin], 1757.

Map 3. The map of the Jaga Kingdom of Kassange in the XVIII Century

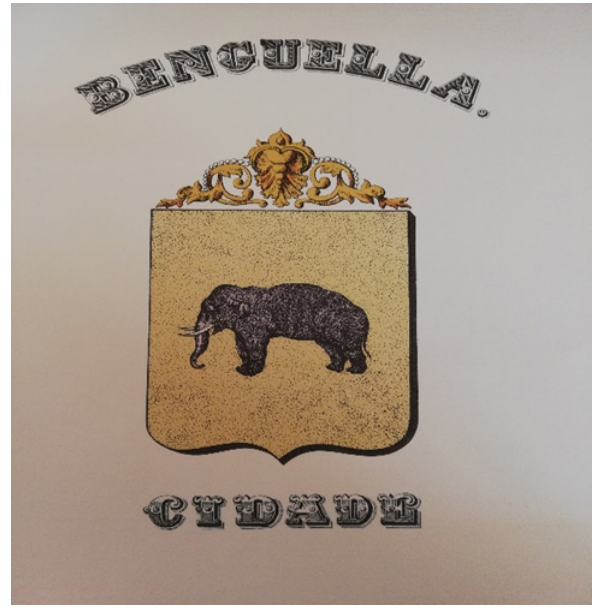

Source: Almeida Langhans, in "Armorial do Ultramar Português" 2 vols. 1966.

Figure 1. Coat of Arms of Benguela
Established the patterns of the decline and reduction of elephant population in the areas and commercial networks connected with Luanda, let us begin the same procedure to Benguela. The original coat of arms of this city, as represented the elephant, what requires that we proceed the inquiry about what meant the representation of this pachyderm in the city coat of arms.(fig.1). The theories divide in two major interpretations: the presence of large populations in that area; or the importance of ivory trade in that city economy.

Related to the first possibility there are a reasonable percentage of documents, that narrate great populations of elephants neighboring Benguela. One of that references his Cavazzi, which mentions a large population of Elephants living in that province: " $/ 20$ - Benguela .... This province is plagued by large numbers of elephants."[29].A more approached account was elaborated by Cadornega, that indicates the distance of days between the nearest ivory 
source and the city: "/he his lords over many lands and vassals, especially the mighty De Gola Amginbo, who, however much he possesses, is by that country and kingdom, which is the city of Sao Phellipe six seven days' journey, where there is the power of parts business. and ivory" [4]. A distance of six days, place elephant presence quite close to the city, what bring us to the question what was the elephant species that habited there? First, it is necessary to define the climate characteristics of Benguela. The region in study was different in clime and habitat from the regions of the north. While the area of Luanda is tropical rainforest, in continuity from the Congo; the inlands of Benguela flora features savannah. By norm the clime of that region it is characterized being warm and dry in the littoral, and mesothermal in the interior [46]. These characteristics are not of the typical habitat of the forest elephant, instead was the realm of another subspecies of elephant, the savannah elephant. Nevertheless, this poses a question, did elephant populations faced the same problems, as is counter species in the north? What obliges us to follow the same methodological process used to understand the impact of ivory demand, in this region? Contraire to Angola regions, in the XVI century, elephant populations were quite closer to that city that in Luanda. For the XVIII century, Elias Correia claims that the access to Ivory was faster in Benguela.The same information is echoed in the documentation of the historical archive where it is officially said that it came from the backlands to Benguela from the inlands./Benguela as so much more advantage than Angola; when the distance is shorter $\rho^{\prime}$ [28]. In the studies of this chronicler, doesn't indicate the regions in particular, from the provenience of the Ivory, or where elephants were present, but there is some official documentation that provide information about that subject for the end of XVIII century and beguiling of the XIX century. In a text collected by António de Albuquerque Felner, there is a report of a Journey to what was designated as the inlands of Benguela. In it, there is abundant information about the geography of the region and some fauna, beside some indication about the Ivory and the Elephant. The Portuguese access to this land was a product of some country-dwellers like the luso-brasilian José de Assumpção e Mello, in 1793, and the Alexandre da Silva Teixeira in 1795. In spite the main commercial objective was slave trade, ivory was also one of the luxury's in demand [30]. "I walked all over the Quibaco .... This Gentio is supremely brave laconic in mankind, very ambitious, has no slave business, almost none, are very fed up with meat and game, especially Elephant"[31]. That route however, if not of knowledge of the African kingdoms of the inland, was utilized by them in an attempt to attracted trade to those regions [32]. Nevertheless, if it is of faster access that in the north lands, we can conclude that elephant presence in trading routes of the city of Benguela, are not present in the surroundings of the city what indicates population decline in the proximities of Benguela. In spite of faster access Maria Emília Madeira Santos, indicated that Portuguese presence in the regions of Bié was quite recent not being prior to 1769 . And, in spite of the same presence, there was not a predominant Portuguese administrative, neither military, forces, present in that area [33]. Only in the last twenty years of the XVIII century, Portuguese forces tried to establish some recognition of their military power against the Ovibundo population: Bailundo, Huambo, Bié and Galangue [30]. One of the measures that Alexandre José Botelho took was to try to create an ordenação (a military regiment) named ordenanças aventureiras of the provinces of Huambo, Quilenges and Bailundo whose objective was to establish a Portuguese military force in that regions. It was within that context that those voyages and written relations of the inlands were elaborated [34]. Despite the military objectives, many resourceful information about the geography and wildlife of that region was provided, collected by a Luso-Brasilian named José D'assunção e Mello [35], that went to the region of Loval, and elaborates a meticulous description of is journey mentioning the rivers, trade, and fauna. That mentioned text, refers to zones where Ivory was traded and it is registered elephants existence. "/ "Whose ambuelas waste away large numbers of slaves, and also the lands of Canunga very near, and likewise the lands of white, either in these lands much slavery is wasted, and these same Sovas de Bunda, for their part, have a Great deal of slavery, and ivory" [31].This text refers to a voyage done in 1799, by Elias Vieira de Andrade, that went to the inferior course of the Luena to the lands of the Bundas [33]. The regions that are mentioned was located in lands of Bunda, west from Luval, that are placed near the lands of the Ambuelas located in the XX century province of Moxico (map 4.). All those regions have a climate designated by humid subtropical clime, and land it's mostly savannah (miombo wood lands). This meant, that large populations of elephants were deep beyond Benguela, reverse to the XVI-XVII century, where they were present in the close inlands, where they had direct and immediate access to ivory. 


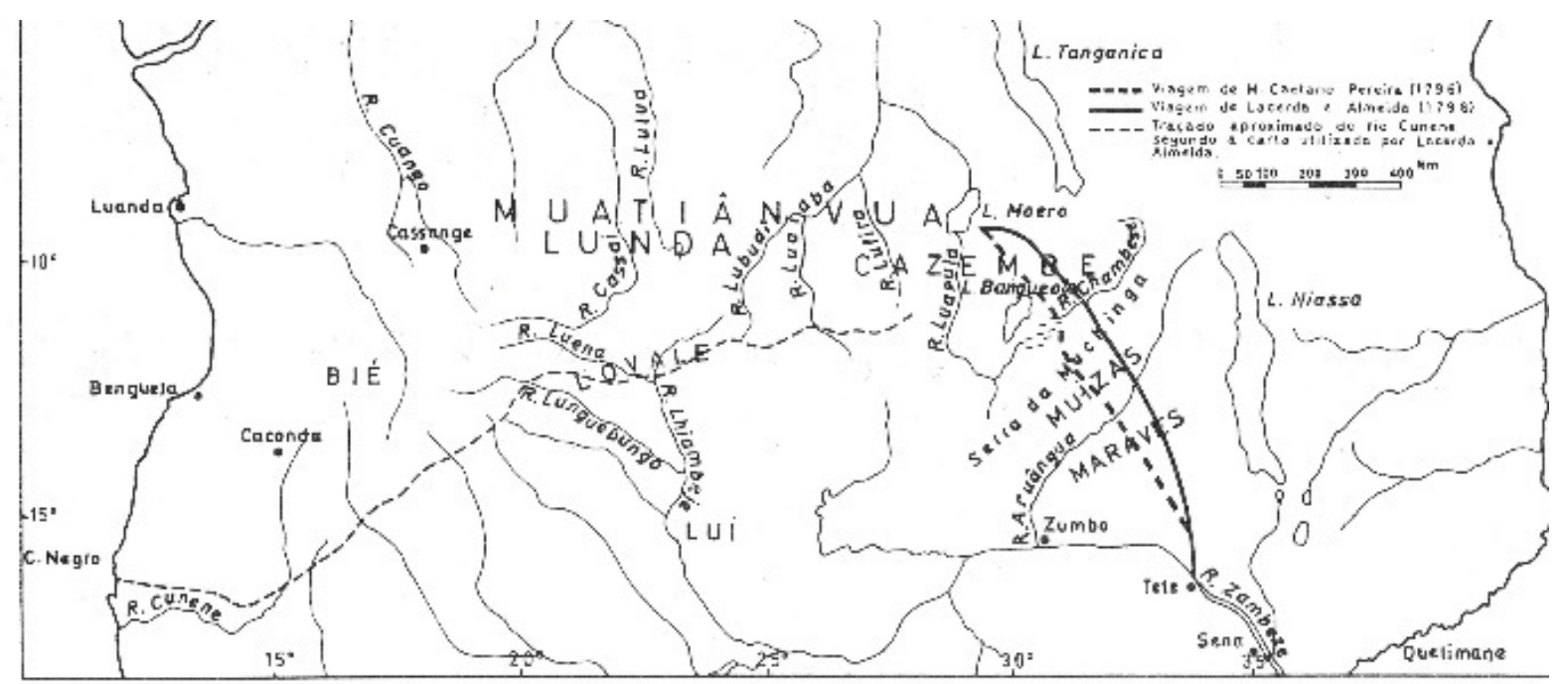

Mapa xu-Primcira lentativa de travessia cientifica da Africa. Viagem do Dr. Tacerda e Almeida, de Tete ao Cazembe (1798)

Source: Maria Emília Madeira Santos, Viagens de Exploração Terrestres Dos Portugueses em África, 2nd edition, Lisbon, Centro de Estudos de Cartografia Antiga/Instituto de Investigação Científica e Tropical, 1988.

Map 4. Voyages from Portuguese travelers to the inlands of Angola including Loval in the XVIII Century

\section{Conclusions}

Contraire to the opinion of N. Thomas Hakanson, the sources encountered in Portuguese archives provide a coherent quantity of information related to elephant habitat, and the impact resultant of ivory demand in is populations in Angola. The accomplishment of this assignment is far from being an easy task, involving a researcher to place its Sherlock Holmes hat and dig deep in the documentation for any reference about the pachyderm and ivory. In other words, demands from the researcher an exhaustive work, locating references to the species, its derived, and intending to establish the regions where the mentions were found, and identify them.

In a general view, in connection with the Ecology History in Africa research themes, we can also include wild life specimens that where killed, in this case study and habitat impact prior to the XIX century. Beside valorize the use of pre XIX century sources that may have present data relatively about description and knowledge of nature.

The selected sources, in spite of being provided by different archives, allowed establishing an academic inquiry, by the combination of the different typology of documentation, about the Elephant habitat, and number of specimens that were killed based in the ivory collected. Not such a general study as those referred, but with base on them, indicates a more concrete relation of ivory demand and impact on population. The developed formula contribute to us establish the number of Elephants killed during the period in study.

This inquire, permit us, within the guidelines of the history of Africa scholars, to establish the relation between the ivory collected and the number of elephants killed. A part from that question permitted the establishing off a relation between the mentioned vectors, to centuries before the great colonial period in the XIX century. In connection with the themes of the History of ecology in Africa, it corresponds to geography and wildlife, providing some accurate information to periods prior to the XIX century included with the themes of that primordial history of environment in Africa. Necessary step, due to being a primary inquire that opens the debate related to the subject.

The predominant species, due to the geographical features, is the Loxodonta Africana except in the region north to Luanda where the species was the Loxondota Cyclotis; if there is possibility to establish the habitat reduction for both elephants subspecies, for now we can only accurate the quantity of hunted elephants only to the first subspecies (what constitutes a challenge for future papers). In general, from the Ivory received in Lisbon, we can determinate that about 12739 elephants were hunted to obtain Ivory. From Benguela, using the city records and the formula, we can observe that 11894 Elephants from the species Loxodonta Africana, were killed for Ivory demand. According to the available sources it is only possible to dispose of records that can provide information about the commercial trading routes and zones with which the Portuguese had contact, which includes many regions and provinces from Angola. From the numbers of collected tusks sent to Lisbon, it was possible to determinate, that mainly in this period; the major percentage of killed elephants span from the age of three to the end of childhood, 5452 killed corresponding to $43 \%$. While adults represented $35 \%$ resulting of a total of 4436 shot; while elephants in their adolescence represented $22 \%$ of the total. This represented a problem to the species renewal, because the gestation period for an elephant it's about nearly two years and mainly it's given birth to one cub. The higher 
percentage and number of cubs killed, meant that the population would have difficulty to renew in spite of the possible large numbers. Proof of that was the short number of adolescents killed, that implied that there was not a deep population renewal.

One question that permit us to establish elephant landscape, is the political reality of XVII and XVIII century Angola, in the case to identify Kassange, in sense that the political realm is seen as ecological identity that provide us clues about what was the species that lived in the different regions. Much of the account is not result of the official sources, but is provided by the travelers and chroniclers that describe the region. Process as consequence of the multiplicity of the name; oblige us to study its political and geographical identity. Apart of the impact on elephant population in the XVIII century, we can determinate an impact on elephant habitat from the XVII century to the XVIII century. The information withdrawal from trading routes allows us to establish, as well, geography on the reduction of Elephant populations in Angola, being ever more distant from the littoral lands. As main cause of that reduction, in the XVIII century Luanda and Benguela, the ivory demand across the mentioned space that connected the littoral lands with the inland.

Nevertheless that process was not uniform to both geographical realities. In Luanda the process was more immediate, while in Benguela to the end of the XVIII century (in spite of the distance), elephant populations could be traced much closer, yet not in the proximity, to that city. Answering to Doran H. Ross; the depredation from the XVII to the ends of the XVIII century had an impact of the disappearing of elephants of the proximal coastal regions and in the zones of the commercial routes. To the XVI-XVII century there was record of population in: Bamba, Benguela, Quissama, Cassanje (lands of Mani kassange). But to the XVIII century, the only reports of elephants it's in the far zones of the inland Kassange, and Ginga, when related to the merchant networks of Luanda; and in the zones of Bié and Luval in the trading zones of Benguela. In a period of one hundred years, it was known a reduction of habitat area in the merchant routes to the inlands.

In other terms the ivory demand in the XVII and XVIII century, had a significant impact on population renewal and in the space that occupied. In spite of the reduction of habitat space, from specific regions in Angola, the impact was more accurate in the renewal capacity of the species. In terms of habitat, the combined data, and due to the more distant trading route and the more accurate information, the population more affected with a deeper withal was the forest elephant while in comparison with the Savannah Elephant that both in the inland of Luanda and Benguela, could be more easily traced. History as discipline can include environmental questions, so we establish a background to current ecological matters.

\section{REFERENCES}

[1] Martha Chaiklin, Ivory in World Histoy - Early Modern Trade in Context, History compass8/6 (2010): 530 - 542.

[2] Carlos M. Cipola., Introdução ao Estudo da História Económica, Lisboa, edições 70, 1993.

[3] Jane Carruthers, "Environmental History in Africa" in Maxine Berg, Luxury and Pleasure in Eighteen century Britain, Oxford, Oxford University Press, 2007.A companion to Global Environmental History Ed. J.R McNeil \& Erin Stewart Mauldin. [S.L], Blackwell Publishing, 2012, pp. $97-115$.

[4] Ílidio do Amaral, O reino do Congo, os Mbundo (ou Ambundos), o Reino dos "Ngola" ou Angola e a presence portuguesa de finais do século XV a meados do século XVI, Lisbon, Instituto de Investigação cientifica Tropical, 1996.

[5] António de Oliveira Cadornega, História Geral das Guerras Angolanas: 1680/ António José Delgado Cadornega; Anot. E corrigido por José Matias Delgado, Lisboa, Agência-Geral do Ultramar, 1972.

[6] Ingrid Silva de Oliveira, As "histórias" de Angola e seus autores nos séculos XVII e XVIII: um estudo de caso dos militares Antonio de Cadornega e Elias Alexandre Correa, Anais do XV encontro regional de História da ANPUH-Rio

[7] Alfred W. Crosby "Ecological Imperialism" in Encyclopedia of World Environmental History Shepard Kretch III ed. New York, Routledge, 2003, pp. 368 - 37

[8] Shepard Krech III, J. R. McNeill, and Carolyn Merchant, "Introduction" in Encyclopedia of World Environmental History Shepard Kretch III ed. New York, Routledge, 2003, pp. ix - xvii.

[9] Eugene P. Odum, Fundamentos da Ecologia, $6^{\circ}$ edition, Lisbon, Fundação Calouste Gulbenkian, 2001.

[10] William Beinart. "African History and Environmental History" African Affairs, Vol. 99, No. 395, Centenary Issue: A Hundred Years of Africa (Apr., 2000), pp. 269-302.

[11] Andrew C. Isenberg," Historicizing Natural Environments: The deep roots of Environmental History", in A companion to Western Historical Thought, pp. $372-375$.

[12] Raman Sukumar, The Living Elephants: Evolutionary, Ecology, Behaviour, and Conservation. New York, Oxford University Press, 2003.

[13] N. Thomas Hakanson "The Human Ecology of World Systems in East Africa: The Impact of the Ivory Trade, Human Ecology, Vol. 32, No. 5, October 2004, pp. 561 591.

[14] Mariza de Carvalho Soares, "Por conto e peso" : O comércio de Marfim no Congo e no Loango, séculos XV-XVII" in Anais do Museu Paulista. São Paulo. N. Sér. v.25. n.1. p. 59-86. jan.-abril, 2017.

[15] Duarte Lopes \& Filipo Pigateffa, Relação do Reino do Congo, Lisbon, Agência Geral do Ultramar, 1951. 
[16] Harvey M Feinberg and Marion Johnson, "The West African Ivory Trade during the Eighteenth Century: The "... and Ivory" Complex" in The International Journal of African Historical Studies, Vol. 15, No. 3, 1982.

[17] Doran H. Ross, an overview, in Elephant: The animal and its ivory in African culture dir. Doran H. Ross. Los Angeles, Fowler Museum of Cultural History, 1992, pp $1-40$.

[18] João Batista Guimes Luis, O Comercio do Marfim e do Poder nos territórios do Kongo, Cacongo, Ngoyo, e Loango: 1796 - 1825, Dissertação de Mestrado em História de África, Lisboa, 2016.

[19] Adelino Torres, Demografia e Desenvolvimento: elementos básicos. Lisbon, Gradiva, 1995

[20] https://www.nationalgeographic.org/media/history-ivory-tra de/ $27-05-2019$

[21] http://animais.culturamix.com/informacoes/caracteristica-d o-elefante 21 - 05 - 2019 15:35].

[22] Alfredo Merino, Os Mamiferos, vol II, Lisboa, Edi Clube, 1998.

[23] Brian J. Huntley, Vladimir Russo, Fernanda Lajes, Nuno Ferrand de Almeida; Biodiversidade de Angola Ciencia e Conservação: uma síntese moderna, Porto, A Ciência é Arte, 2019.

[24] Martha Chaiklin, Ivory in World Histoy - Early Modern Trade in Context, History compass8/6 (2010): 530 - 542.

[25] Gastão de Sousa Dias, As relações de Angola, Imprensa da Universidade de Coimbra, Coimbra, 1934, pp. $51-66$.

[26] José M. Prats Estivill, “Angola” in Geografia Universal dir. Carlos Carrareras Verdguer, Vol. 6, Barcelona, Óceano-Éxito, 1991, pp. 2208 - 2213.

[27] A.H.U, Angola, Concelho Ultramarino, Caixa 95, doc $\mathrm{n}^{\circ} 9$, $10-03-1800$

[28] Elias Alexandre da Silva Correia, História de Angola/Elias Alexandre da Silva Corrêa/Nota Previa Manuel Múria, Lisboa, Ática, 1937.

[29] P. João António Cavazzi,, Descrição Histórica dos três reinos do Congo, Matamba, Angola, trad. notas e indices P. Graciano Maria de Leguzzano O.M Cap. Vol. 1, Lisboa, Junta de Investigação do Ultramar, 1965.

[30] René Pélissser, História das Campanhas de Angola, vol. 1, Lisbon, Editorial Estampa, 1986.

[31] Alfredo de Albuquerque Felner, Angola: apontamentos sobre a colonização dos Planaltos e Litoral, Vol II, Lisbon, Agência Geral das Colónias, 1940.].

[32] Maria Emília Madeira Santos, Viagens de Exploração Terrestres Dos Portugueses em África, 2nd edition, Lisbon, Centro de Estudos de Cartografia Antiga/Instituto de Investigação Científica e Tropical, 1988.

[33] Maria Emília Madeira Santos, Nos caminhos de África, Lisbon, Instituto de Investigação Cientifica Tropical, 1998.

[34] Pascoal Leite de Aguiar, Administração do Colonial Portuguesa no Congo, em Angola e em Benguela, Lisbon, Sociedade Histórica da Independencia de Portugal, 2005.
[35] Teixiera da Mota, A Cartografia Antiga da África Central, Sociedade de Estudos de Moçambique, 1964. 